\title{
Usulan Perancangan Tata Letak Gudang dengan Menggunakan Metode Class-Based Storage (Studi Kasus di PT Heksatex Indah, Cimahi Selatan)
}

\author{
Recommendation For Designing New Storage Layout \\ Using Class-Based Storage Method \\ (Case Study at PT Heksatex Indah, Cimahi Selatan)
}

\author{
Johan, Kartika Suhada \\ Program Studi Teknik Industri, Fakultas Teknik, Universitas Kristen Maranatha, Bandung \\ E-mail : antoniusjohan22@yahoo.com, tikas56@gmail.com
}

\begin{abstract}
Abstrak
PT Heksatex Indah adalah perusahaan yang bergerak di bidang tekstil rajut lusi. Masalah yang dihadapi oleh perusahaan ini adalah operator mengalami kesulitan dalam melakukan aktivitas pemasukan, pencarian, dan pengeluaran kain dari/ke gudang pra-proses (kain grey) dikarenakan kain diletakkan di area gang dan banyak jenis kain yang sama berada di beberapa lokasi penyimpanan. Dalam memecahkan permasalahan yang dihadapi perusahaan, digunakan metode class-based storage dalam merancang tata letak gudang yang baru dengan menggunakan alat penyimpanan kain usulan yang sudah dimodifikasi dari alat penyimpanan kain sebelumnya. Selain itu, diusulkan pula penggunaan alat material handling baru, yaitu trolley kecil, untuk memudahkan kerja operator supaya tidak membawa gulungan kain satu per satu. Berdasarkan hasil perhitungan, jika perusahaan menerapkan tata letak usulan, maka terjadi penghematan jarak rata-rata dari pintu ke lokasi penyimpanan sebesar 64,53 m dan 52,35 \%. Tata letak kain usulan memiliki tata letak yang lebih rapi dan teratur dibandingkan dengan tata letak kain saat ini karena kain yang sama berada di satu lokasi dan tidak terdapat kain yang disimpan di gang yang menghalangi operator dalam melakukan aktivitasnya.
\end{abstract}

Kata kunci : Class-based, Gudang, Material Handling, Kain, Jarak Rata-rata

\begin{abstract}
PT Heksatex Indah is a company engaged in the field of warp knitting textile. The problems faced by this company is the operator is having difficulty in performing activities of storing, searching, and taking fabric from/to warehouse pre-process (gray cloth) because the fabric is placed in the aisle area and a lot of same types fabrics are placed in multiple locations. To solve the problems faced by the company, the class-based storage methods is used in designing the layout of a new warehouse by using a new fabric storage device that have been modified from the previous fabric storage devices. In addition, the authors also propose using a new material handling tools, it is a small trolley to facilitate the work of operators so they do not need to carry a roll of fabric one by one. Based on calculations, if the company implemented the proposed layout, it improved the average distance from the door to the storage location by $64.53 \mathrm{~m}$ and $52.35 \%$. The proposed layout has a more neat and orderly layout compared to the current layout because there are fabrics which are stored in the aisle and blocking the operators to do their activities in the current layout.
\end{abstract}

Key Words : Class-based, Storage, Material Handling, Fabrics, Average Distance

\section{Pendahuluan}

Setiap perusahaan manufaktur, baik perusahaan besar, menengah ataupun kecil pastilah mempunyai gudang untuk menyimpan bahan baku, barang setengah jadi, maupun produk jadi. Pengaturan barang dalam gudang perlu mendapat perhatian agar mudah dalam penyimpanan maupun pengeluaran barang dari gudang. Di samping itu, dengan penataan barang yang baik dapat 
memudahkan pencarian barang yang diinginkan. PT Heksatex Indah adalah perusahaan manufaktur yang bergerak di bidang tekstil warp knitting atau rajut lusi yang berlokasi di Cimahi Selatan. Perusahaan ini memproduksi kain yang secara umum dikelompokkan menjadi 2 jenis kain, yaitu kain bercorak dasar dan bercorak kembang yang memiliki motif dan warna yang beragam. Saat ini, perusahaan memiliki 3 jenis gudang, yaitu gudang bahan baku, gudang barang setengah jadi (kain grey), dan gudang produk jadi. Dari ketiga jenis gudang ini, berdasarkan rekomendasi yang diberikan oleh perusahaan, dilakukan penelitian di gudang barang setengah jadi. Dari hasil pengamatan terlihat bahwa penataan kain di gudang barang setengah jadi belum baik. Hal ini terlihat dari tata letak kain yang tidak beraturan, dimana kain disimpan di area gang dan kain yang sejenis tidak berada di lokasi yang sama, sehingga membuat operator gudang mengalami kesulitan dalam proses pemasukan, pencarian, dan pengeluaran kain. Oleh karena itu akan dilakukan perancangan tata letak kain yang lebih baik, sehingga proses penanganan kain dalam gudang dapat berlangsung dengan lancar dan cepat.

Berhubung luasnya ruang lingkup penelitian yang dapat dilakukan, maka ditetapkan batasan sebagai berikut:

1. Data keluar-masuk kain dari/ke gudang yang digunakan diambil dari data tahun 2014 .

2. Tidak membahas faktor biaya material handling $(\mathrm{OMH})$.

Asumsi yang digunakan sebagai berikut:

1. Tidak terjadi perubahan luas lantai gudang.

2. Tidak terjadi penambahan atau pengurangan alat penyimpanan kain.

Tujuan penelitian ini adalah sebagai berikut :

1. Mengusulkan penataan kain dalam gudang yang sebaiknya diterapkan perusahaan.

2. Mengemukakan kelebihan dari penataan kain dalam gudang usulan.

3. Mengusulkan alat material handling yang sebaiknya digunakan oleh perusahaan.

4. Mengusulkan alat penyimpanan kain yang sebaiknya digunakan perusahaan.

\section{Tinjauan Pustaka}

\subsection{Perancangan Tata Letak Fasilitas}

Perencanaan tata letak fasilitas meliputi penentuan lokasi sistem manufaktur dan perencanaan fasilitas yang meliputi perancangan terhadap fasilitas, tata letak, serta penanganan bahan yang mendukung aktivitas produksi di sebuah perusahaan [Tompkins, at al., 2003].

Tata letak adalah suatu landasan utama dalam dunia industri. Tata letak pabrik (plant layout) atau tata letak fasilitas (facilities layout) dapat didefinisikan sebagai tata cara pengaturan fasilitasfasilitas pabrik guna menunjang kelancaran proses produksi [Wignjosoebroto, 2003].

\subsection{Perancangan Tata Letak Gudang}

Pergudangan memiliki fungsi untuk memaksimalkan utilisasi berbagai sumber daya dalam rangka memenuhi permintaan pelanggan atau memaksimalkan pemenuhan permintaan pelanggan dengan sumber daya yang terbatas. Oleh karena itu, perencangan gudang diharapkan dapat memaksimalkan utiliasi ruang, peralatan dan pekerja, serta kemudahan akses dan perlindungan material-material yang tersimpan di dalamnya [Tompkins, et al., 2003].

Agar tujuan-tujuan perencanaan tata letak gudang dapat terpenuhi, maka terdapat lima prinsip area penyimpanan yang perlu diperhatikan secara keseluruhan. Kelima prinsip tersebut adalah sebagai berikut: [Tompkins, et al., 2003]

1. Popularitas

Pada umumnya, $85 \%$ dari keseluruhan proses keluar-masuk barang dari/ke gudang terjadi atas $15 \%$ dari keseluruhan barang yang disimpan. Untuk memaksimalkan proses keluar-masuk barang, 15\% barang yang merupakan barang popular tersebut harus disimpan sehingga jarak 
perpindahannya ke titik keluar-masuk barang dapat diminimalkan. Dengan kata lain, semakin popular suatu barang, maka semakin pendek pula jarak perpindahannya. Hal tersebut dapat dicapai dengan menyimpan barang-barang popular pada area penyimpanan terdekat dengan titik keluar-masuk barang.

2. Kesamaan

Barang-barang yang diterima dan dikirimkan pada saat yang bersamaan hendaknya disimpan pada area yang sama. Dengan demikian, frekuensi perpindahan dalam aktivitas penerimaan dan pengiriman barang dapat diminimalkan.

3. Ukuran

Setiap barang hendaknya disimpan di area yang sesuai dengan ukurannya. Untuk mengetahui hal tersebut, perlu diadakan berbagai macam ukuran lokasi penyimpanan. Pada umumnya, barang yang berat, berukuran besar, dan sulit ditangani harus disimpan dekat dengan titik keluar-masuk gudang. Namun, penempatan ruang juga perlu dilakukan berdasarkan kemudahan penanganan dan popularitas barang-barang tersebut.

4. Karakteristik

Metode penyimpanan barang dengan mempertimbangkan karakteristiknya seringkali bertentangan dengan prinsip popularitas, kesamaan, dan ukuran. Namun, beberapa karakteristik barang yang perlu diperhatikan adalah usia, bentuknya yang tidak umum dan mudah hancur, sifatnya yang berbahaya, tingkat keamanan, dan kompabilitas.

5. Utilisasi Ruang

Perancangan tata letak harus dilakukan agar dapat memaksimalkan utilisasi ruang dan juga memaksimalkan tingkat pelayanan yang dihasilkan. Faktor-faktor yang pelu dipertimbangkan dalam perancangan tata letak adalah:

1) Konservasi ruang, meliputi maksimasi konsentrasi dan utilisasi ruang serta minimasi honeycombing.

2) Keterbatasan ruang, dapat juga terjadi akibat adanya rangka bangunan, pemadam kebakaran tinggi dari atas, batas muatan lantai, tinggi penyangga bangunan dan batas tinggi tumpukan material yang aman.

3) Kemudahan akses, dapat dicapai dengan merancang lebar gang yang cukup lebar untuk penanganan barang yang efisien dan penempatannya agar setiap area penyimpanan memiliki akses terhadap gang tersebut.

4) Orderliness, penandaan gang dengan baik dapat menggunakan aisle tape atau cat. Ruang kosong dalam area gudang harus dihindari dan harus dikoreksi dimana hal itu mungkin terjadi.

\subsection{Metode Penyimpanan Gudang}

Dalam perancangan tata letak gudang, tidak cukup hanya menata tata letak fisik saja. Tetapi juga diperlukan penentuan metode penyimpanan atau penempatan produk. Terdapat 4 metode penyimpanan gudang, yaitu: [Francis, et al., 1992]

1. Dedicated Storage Policy

Dedicated storage atau yang disebut juga metode penyimpanan fixed lot storage merupakan metode penyimpanan gudang yang menggunakan penempatan lokasi yang spesifik untuk setiap komponen atau barang yang disimpan. Hal ini dikarenakan, setiap satu lokasi penyimpanan diberikan (dedicated) pada satu komponen atau barang yang spesifik. Dengan demikian, jumlah lokasi penyimpanan yang disediakan harus mampu memenuhi kebutuhan maksimal dari komponen atau produk.

2. Random Storage Policy

Random storage atau yang disebut juga metode penyimpanan floating lot storage merupakan metode penyimpanan yang membuat lokasi penyimpanan untuk komponen atau produk tertentu berubah (float) setiap waktu atau dengan kata lain komponen atau produk tidak memiliki letak/lokasi yang pasti. Pada prakteknya, randomized storage didefinisikan sebagai berikut: Saat barang datang maka barang tersebut akan disimpan di lokasi terdekat yang kosong/available. Penyimpanan atau pengambilan dengan metode random ini tidak dilakukan secara random atau 
acak. Penyimpanan atau pengambilan komponen hanya memperhatikan jarak terdekat dengan titik keluar masuk komponen atau produk di gudang berdasarkan sistem FIFO (first-in, first-out)

3. Class-Based Storage Policy

Metode penyimpanan ini merupakan metode penyimpanan yang berada di antara aturan dedicated storage dan random storage sehingga metode ini menjadi lebih fleksibel dan banyak digunakan. Dengan menggunakan metode class based storage, produk atau komponen dibagi ke dalam tiga, empat, atau lima kelas berdasarkan perbandingan throughput (T) dengan storage (S). Produk yang merupakan fast moving product dikategorikan sebagai produk kelas 1 dan berikutnya adalah produk kelas 2, selanjutnya produk kelas 3, dan seterusnya. Aturan dedicated storage digunakan untuk penentuan lokasi kelas, sedangkan random storage digunakan untuk penentuan lokasi di dalam kelas. Penempatan komponen atau produk di dalam kelas berdasarkan jenis maupun ukuran tertentu.

4. Shared Storage Policy

Dalam usaha untuk mengurangi kebutuhan ruang penyimpanan pada metode penyimpanan dedicated storage, para manajer gudang menggunakan variasi dari metode dedicated storage sebagai jalan keluar dimana penempatan produk pada lokasi dilakukan dengan lebih hati-hati. Komponen-komponen yang berbeda menggunakan slot penyimpanan yang sama namun pada waktu yang berbeda-beda, walaupun hanya satu komponen yang menempati satu slot tersebut. Model penyimpanan seperti ini dinamakan shared storage.

\subsection{Langkah-langkah Metode Penyimpanan Class-Based Storage}

Penyimpanan berdasarkan class-based storage sama dengan langkah-langkah penyimpanan dedicated storage. Langkah-langkah penentuan lokasi penyimpanan dengan dedicated storage, yaitu sebagai berikut : [Francis, et al., 1992]

1. Menentukan kebutuhan ruangan (Space requirements)

Dengan metode dedicated storage, produk ditugaskan ke lokasi tertentu. Jumlah lokasi harus sebanding dengan tingkatmaksimum persediaan dari semua produk yang ada. Jika gudang menyimpan beragam produk, maka ruang yang dibutuhkan setara dengan jumlah dari kebutuhan gudang maksimum dari masing-masing produk. Pendekatan yang dapat digunakan untuk menentukan ukuran gudang adalah pendekatan service level.

2. Menetapkan produk ke lokasi penyimpanan/pengambilan

Dengan metode dedicated storage, penetapan produk ke lokasi penyimpanan/pengambilan merupakan suatu usaha untuk meminimasi waktu yang dibutuhkan untuk proses penyimpanan dan pengambilan barang di gudang. Masalah penugasan dengan dedicated storage dinyatakan dengan rumus sebagai berikut :

Minimasi $\mathrm{f}(\mathrm{x})=\sum_{i=1}^{m} \sum_{j=1}^{n} \sum_{k=1}^{s} \frac{T_{j}}{S_{j}}\left[P_{i, j} d_{i, k} X_{j, k}\right]$

Subject to

$\begin{array}{lr}\sum_{j=1}^{n} X_{j, k}=1, & \mathrm{k}=1,2, \ldots \ldots, \mathrm{s} \\ \sum_{k=1}^{s} X_{j, k}=S_{j,} & \mathrm{j}=1,2, \ldots \ldots, \mathrm{n} \\ X_{j, k}=(0,1) & \text { untuk semua j dan k }\end{array}$

dimana:

$\mathrm{s}=$ jumlah lokasi penyimpanan

$\mathrm{n}=$ jumlah produk

$\mathrm{m}=$ jumlah pintu

$\mathrm{T}_{\mathrm{j}}=$ jumlah perjalanan untuk setiap produk

$\mathrm{S}_{\mathrm{j}}=$ Kebutuhan penyimpanan untuk produk $\mathrm{j}$, dinyatakan dalam jumlah slot penyimpanan

$\mathrm{P}_{\mathrm{i}, \mathrm{j}}=$ Persentase perjalanan storage untuk produk j dari/ke titik input/output (I/O) $\mathrm{i}$

$\mathrm{d}_{\mathrm{j}, \mathrm{k}}=$ Jarak (atau waktu) yang dibutuhkan untuk perjalanan antara titik I/O $\mathrm{j}$ dengan lokasi storage $\mathrm{k}$

$\mathrm{X}_{\mathrm{j}, \mathrm{k}}=$ Angka 1 menunjukkan jika produk $\mathrm{j}$ diletakkan pada lokasi $\mathrm{k}$

$=$ Angka 0 jika tidak diletakkan

$\mathrm{f}(\mathrm{x})=$ Jarak (waktu) rata-rata yang ditempuh 
Ketika persentase pintu dan lokasi penyimpanan/pengambilan untuk seluruh produk adalah sama, maka untuk menghasilkan solusi yang optimal digunakan ketentuan sebagai berikut:

a. Urutkan produk berdasarkan $\mathrm{Tj}$ dan $\mathrm{Sj}$, yaitu seperti berikut :

$$
\frac{T_{1}}{S_{1}} \geq \frac{T_{2}}{S_{2}} \geq \ldots \geq \frac{T_{n}}{S_{n}}
$$

b. Hitung nilai fk untuk semua lokasi penyimpanan, dimana:

$$
f_{k}=\sum_{i=1}^{m} p_{i} d_{i k}
$$

c. Alokasikan produk 1 ke lokasi storage $\mathrm{S}_{1}$ yang memiliki nilai jarak rata-rata tempuh $\mathrm{f}(\mathrm{x})$ terkecil, penugasan produk 2 ke lokasi storage/warehouse $\mathrm{S}_{2}$ yang memiliki nilai fx terkecil berikutnya, dan seterusnya

\subsection{Material Handling}

Pemindahan bahan atau material handling adalah suatu aktivitas yang sangat penting dalam kegiatan produksi dan memiliki kaitan erat dengan perencanaan tata letak fasilitas produksi. Aktivitas ini sendiri sebetulnya merupakan aktivitas yang diklarifikasikan "non-produktif" sebab tidak memberikan nilai perubahan apa-apa terhadap material atau bahan yang dipindahkan. Pada saat pemindahan bahan tidak akan terjadi perubahan bentuk, dimensi maupun sifat-sifat fisik atau kimiawi dari material yang dipindahkan. Di sisi lain justru kegiatan pemindahan bahan/material handling tersebut akan menambah biaya (cost). Dengan demikian sedapat-dapatnya aktivitas pemindahan bahan tersebut dihilangkan atau paling tepat untuk menekan biaya pemindahan bahan tersebut adalah memindahkan bahan pada jarak yang sependek-pendeknya dengan mengatur tata letak fasilitas produksi atau departemen yang ada. [Wignjosoebroto, 2003]

Berikut ada beberapa istilah yang umum dijumpai dalam pembahasan mengenai material handling seperti halnya:

- Transport, adalah pemindahan bahan dalam satuan berat (unit load) atau containers melalui suatu lintasan yang jaraknya lebih dari 5 feet atau sekitar 1,5 meter.

- Transfer, adalah pemindahan bahan melalui lintasan yang jaraknya kurang dari 5 feet atau sekitar 1,5 meter.

- Bulk Material, adalah bahan atau material yang dalam pemindahan tidak memerlukan bag, barrel, bottle, can, drum, dan lain-lain.

- Packaged Material, adalah bahan atau material yang dalam pemindahan akan memerlukan wadah atau tempat untuk membawanya dengan mudah seperti bag, box, drum, bottle, dan lainlain.

- Unit Load, menunjukkan sejumlah packaged unit tertentu yang bisa dimuat dalam skid box, pallets, dan lain-lain.

- Rehandle, adalah aktivitas penurunan muatan yang ada dalam pallets, skid box, dan lain-lain.

\section{Pembahasan}

\subsection{Perhitungan Jarak Rata-rata dari Blok ke Pintu Gudang Saat Ini}

Perhitungan jarak rata-rata berfungsi untuk menentukan seberapa jauh jarak dari setiap blok (terdapat 7 blok) ke pintu keluar-masuk gudang, dimana terdapat 2 pintu keluar-masuk gudang. Jarak rata-rata akan digunakan sebagai parameter pembanding dengan tata letak usulan yang dirancang. Sebelum melakukan perhitungan jarak rata-rata, harus dilakukan perhitungan nilai lokasi gudang terlebih dahulu untuk mendapatkan nilai untuk setiap lokasi di gudang.

\subsubsection{Persentase Pintu Saat Ini}

Perhitungan persentase pintu digunakan untuk menghitung nilai lokasi pada metode perhitungan jarak rectilinear, sedangkan persentase ditentukan dari perbandingan antara jumlah frekuensi kainkain yang melewati pintu tersebut dengan total frekuensi seluruh kain. Pada kondisi gudang saat ini 
hanya kain TS yang melewati pintu 2, sedangkan kain DN, TN, dan TV melewati pintu 1. Perhitungan persentase pintu ditunjukkan pada tabel 1.

Tabel 1 Persentase Pintu Saat Ini

\begin{tabular}{|c|c|c|c|c|}
\hline \multirow{2}{*}{$\begin{array}{c}\text { Jenis } \\
\text { Corak }\end{array}$} & $\begin{array}{c}\text { Frekuensi jumlah kain keluar } \\
\text { masuk gudang }\end{array}$ & \multicolumn{3}{|c|}{ Penggunaan Pintu } \\
\cline { 3 - 3 } & 823 & Pilihan Pintu & Frekuensi & Persentase (\%) \\
\hline Kain DN & 1145 & Pintu 1 & \multirow{2}{*}{2579} & \multirow{2}{*}{93,37} \\
\hline Kain TN & 611 & Pintu 1 & \\
\hline Kain TV & 183 & Pintu 1 & & 6,63 \\
\hline Kain TS & $\mathbf{2 7 6 2}$ & Pintu 2 & 183 & \\
\hline Total & \multicolumn{2}{|c}{} \\
\cline { 2 - 3 }
\end{tabular}

Contoh perhitungan :

Frekuensi Pintu $1=$ Frek. kain DN + Frek. kain TN + Frek. kain TV

$=823+1145+611=2579$ gulungan kain

Persentase Pintu $1=\frac{\text { Frekuensi Pintu } 1}{\text { Frekuensi Keseluruhan }} * 100 \%$

$$
=\frac{2579}{2762} * 100 \%=93,37 \%
$$

\subsubsection{Nilai Lokasi Gudang Saat Ini}

Perhitungan nilai lokasi gudang saat ini menggunakan metode perhitungan jarak rectilinear, yaitu metode perhitungan dengan menggunakan kotak-kotak berukuran $20 \mathrm{~cm}$ x $20 \mathrm{~cm}$ sebagai patokan ukuran untuk gudang berukuran $1500 \mathrm{~cm} \times 2400 \mathrm{~cm}$. Perhitungan nilai lokasi gudang saat ini ditunjukkan pada gambar 1. Sebagai contoh, perhitungan nilai lokasi gudang adalah sebagai berikut:

$\mathrm{S}_{1}=$ Jarak ke titik tengah lokasi dari $\mathrm{P}_{1}$

$\mathrm{S}_{2}=$ Jarak ke titik tengah lokasi dari $\mathrm{P}_{2}$

Perhitungan $\mathrm{S}_{1}$ dan $\mathrm{S}_{2}$ berdasarkan panjang dan lebar kotak

Nilai lokasi (ungu) $=\left(\right.$ Persentase $\left.\mathrm{P}_{1} * \mathrm{~S}_{1}\right)+\left(\right.$ Persentase $\left.\mathrm{P}_{2} * \mathrm{~S}_{2}\right)$

$$
\begin{aligned}
& =(93,37 \% *(1510+10))+(6,63 \% *(230+10)) \\
& =1419,22+15,91 \\
& =1435,13 \mathrm{~cm} \approx 14,35 \mathrm{~m} .
\end{aligned}
$$


USULAN PERANCANGAN TATA LETAK GUDANG (Johan, dkk.)
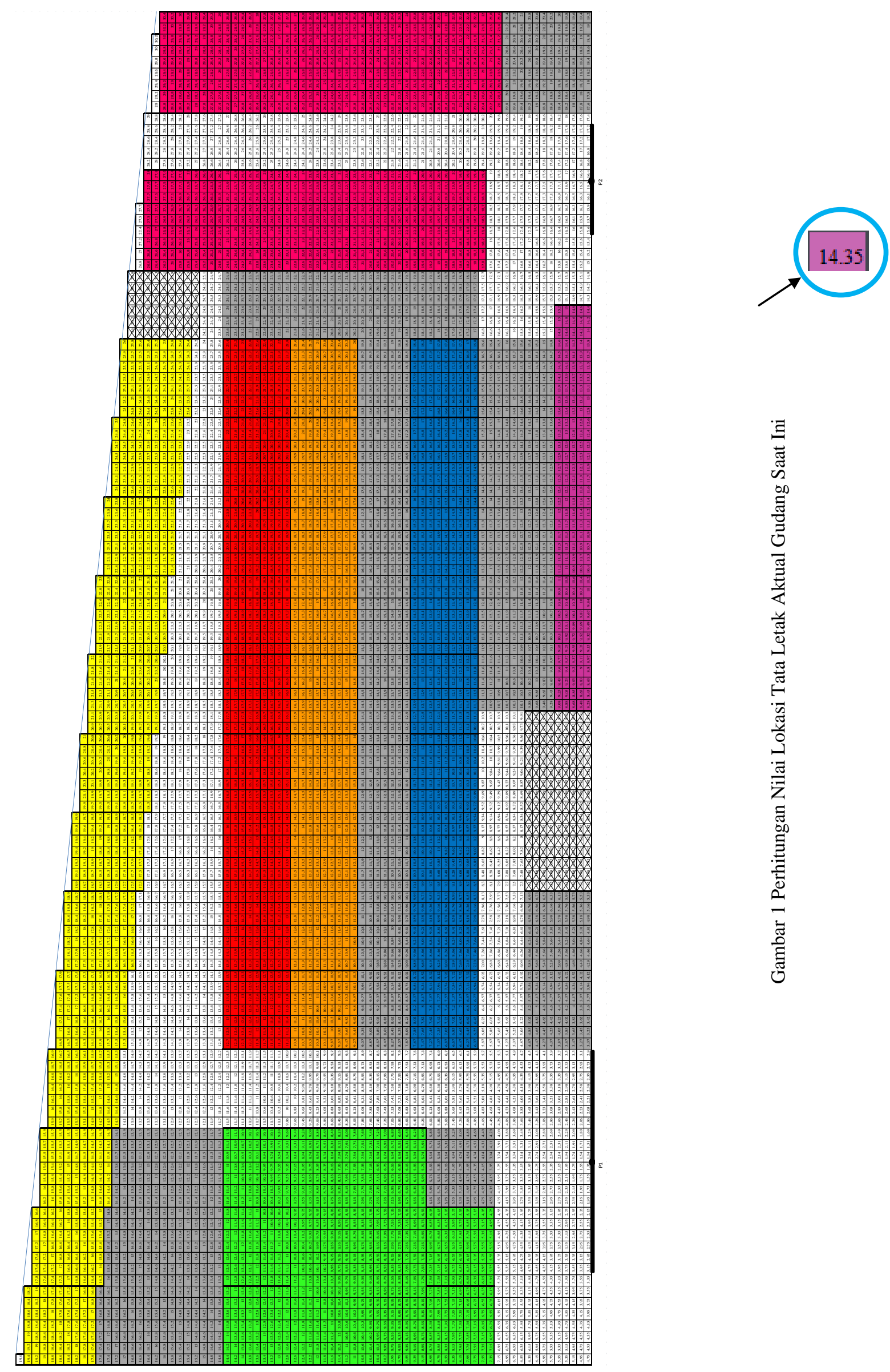

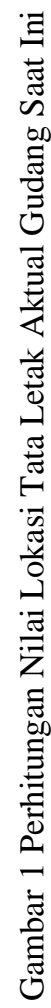




\subsubsection{Jarak Rata-rata dari Lokasi ke Pintu Gudang Saat Ini}

Jarak rata-rata dari lokasi ke pintu gudang dihitung dari total nilai jarak dari setiap lokasi per blok dibagi dengan jumlah lokasi (kotak) setiap blok. Perhitungan jarak rata-rata dari pintu ke seluruh blok ditunjukkan dalam tabel 2 .

Tabel 2 Jarak Rata-rata dari Blok ke Pintu Gudang Saat Ini

\begin{tabular}{|c|c|c|c|c|c|c|c|}
\hline \multirow{2}{*}{ Blok } & \multicolumn{4}{|c|}{ Alat Penyimpanan } & \multirow{2}{*}{ Jumlah Lokasi } & \multirow{2}{*}{ Total Jarak (m) } & \multirow{2}{*}{ Jarak Rata-rata (m) } \\
\hline & Pallet & Rak Tingkat 2 & Rak Tingkat 3 & Tanpa Alat Penyimpanan & & & \\
\hline $\mathrm{A}$ & 9 & 4 & 0 & 0 & 819 & 16069,17 & 19,62 \\
\hline $\mathrm{B}$ & 6 & 3 & 0 & 0 & 567 & 9808,89 & 17,30 \\
\hline $\mathrm{C}$ & 6 & 3 & 0 & 0 & 567 & 8788,29 & 15,50 \\
\hline $\mathrm{D}$ & 6 & 3 & 0 & 0 & 567 & 6973,89 & 12,30 \\
\hline$E$ & 0 & 0 & 3 & 0 & 180 & 2047,98 & 11,38 \\
\hline $\mathrm{F}$ & 0 & 0 & 0 & 10 & 810 & 18728,44 & 23,12 \\
\hline $\mathrm{G}$ & 8 & 3 & 0 & 0 & 693 & 7138,70 & 10,30 \\
\hline
\end{tabular}

Contoh perhitungan Blok B (blok yang diwarnai dengan warna merah pada gambar 1) :

- Rak tingkat 2 digunakan sebagai penopang untuk kain yang ditumpuk pada pallet. Sedangkan pallet digunakan untuk menumpuk kain yang berukuran besar namun membutuhkan rak tingkat 2 supaya dapat ditumpuk tinggi. Terdapat 3 rak tingkat 2 dan 6 pallet pada blok B, seperti ditunjukkan dalam gambar 2.

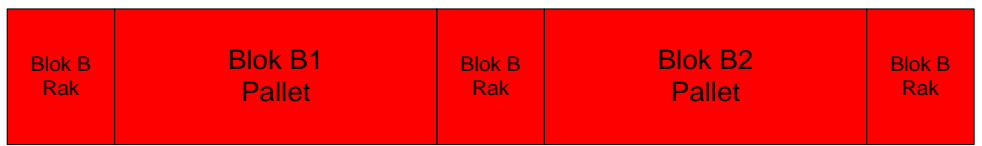

Gambar 2 Posisi Pallet dan Rak Tingkat 2 di Blok B

- Alasan metode penyimpanan dibuat sedemikian rupa adalah karena kain tidak dapat ditumpuk tinggi apabila tidak terdapat penopang disamping kiri dan kanan kain sehingga metode penyimpanan kain ditunjukkan pada gambar 3.
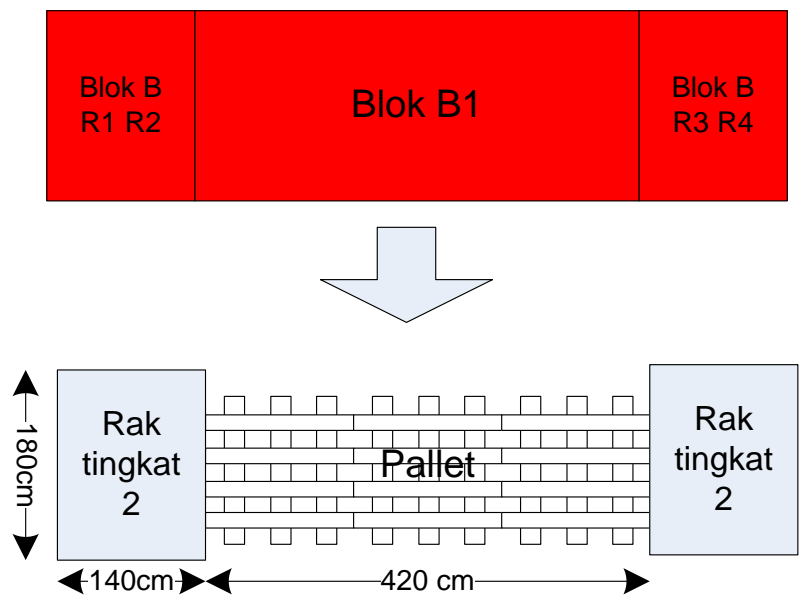

Gambar 3 Metode Penyimpanan Kain Saat Ini

- Jumlah lokasi adalah jumlah kotak yang terdapat di blok B

- Total jarak adalah nilai skor yang terdapat di kotak-kotak pada blok B

- Jarak rata-rata dari blok ke pintu gudang didapatkan dari total jarak dibagi dengan jumlah lokasi Jarak rata-rata dari blok ke pintu gudang $=\frac{\text { Total Jarak }}{\text { Jumlah lokasi }}=\frac{9808,89 \mathrm{~m}}{567 \text { slot }}$

$$
=17,30 \mathrm{~m}
$$




\subsection{Perancangan Tata Letak Usulan}

Setelah dilakukan perhitungan utilisasi dan jarak rata-rata gudang saat ini, dilakukan perancangan tata letak usulan dengan menggunakan metode Class-based Storage, dimana perancangan tata letak kain berdasarkan pengelompokkan kelas yang sudah ditentukan dari perusahaan, yaitu berdasarkan jenis kain dengan kode DN, TN, TS, dan TV.

\subsubsection{Data Persediaan Maksimum Bulanan Gudang}

Berdasarkan data persediaan bulanan dari setiap jenis kain yang dimiliki perusahaan selama periode 2014, penulis mendapatkan data persediaan bulanan maksimum seperti yang ditunjukkan pada tabel 3 .

Tabel 3 Data Persediaan Maksimum Bulanan

\begin{tabular}{|c|c|c|c|c|}
\hline \multirow{2}{*}{ Bulan } & \multicolumn{4}{|c|}{ Jenis Kain } \\
\cline { 2 - 5 } & Kain DN & Kain TN & Kain TS & Kain TV \\
\hline Januari & 265 & 374 & 110 & 112 \\
\hline Februari & 235 & 353 & 111 & 273 \\
\hline Maret & 114 & 47 & 116 & 370 \\
\hline April & 209 & 579 & 113 & 380 \\
\hline Mei & 179 & 570 & 120 & 315 \\
\hline Juni & 242 & 368 & 119 & 159 \\
\hline Juli & 358 & 461 & 101 & 292 \\
\hline Agustus & 370 & 283 & 89 & 381 \\
\hline September & 372 & 574 & 73 & 204 \\
\hline Oktober & 233 & 375 & 58 & 248 \\
\hline November & 359 & 317 & 92 & 185 \\
\hline Desember & 331 & 451 & 124 & 322 \\
\hline Persediaan Max & $\mathbf{3 7 2}$ & $\mathbf{5 7 9}$ & $\mathbf{1 2 4}$ & $\mathbf{3 8 1}$ \\
\hline
\end{tabular}

Data persediaan maksimum di atas akan digunakan sebagai dasar perhitungan luas lantai yang dibutuhkan.

\subsubsection{Alat Penyimpanan Kain Usulan}

Alat penyimpanan kain yang diusulkan merupakan hasil modifikasi dari alat penyimpanan kain yang lama, yaitu rak tingkat 2. Dasar perancangan rak usulan adalah agar kain dapat tersangga sepenuhnya (panjang kain maksimum $270 \mathrm{~cm}$, sedangkan panjang rak hanya $180 \mathrm{~cm}$ ) dan alat penyimpanan yang lama masih bisa dimanfaatkan. Modifikasi yang dilakukan oleh penulis adalah menggabungkan 2 buah rak tingkat 2 yang berukuran 180 × 140 × 320 ke arah panjang, sehingga menjadi rak berukuran $360 \times 140 \times 320$. Usulan alat penyimpanan kain tersebut dapat dilihat pada gambar 4. 


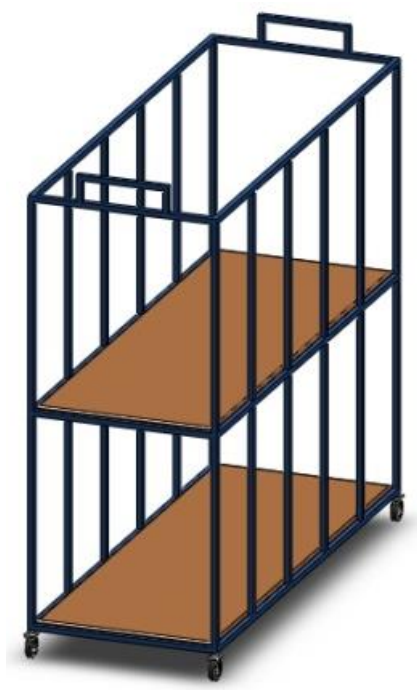

Gambar 4 Alat Penyimpanan Kain Usulan

Alat penyimpanan kain usulan pada gambar 5.4 menggunakan 2 buah rak tingkat 2 saat ini yang disatukan ke arah panjang, sehingga memiliki dimensi yang berukuran 360 × 140 x 320 seperti ditunjukkan pada gambar 5.
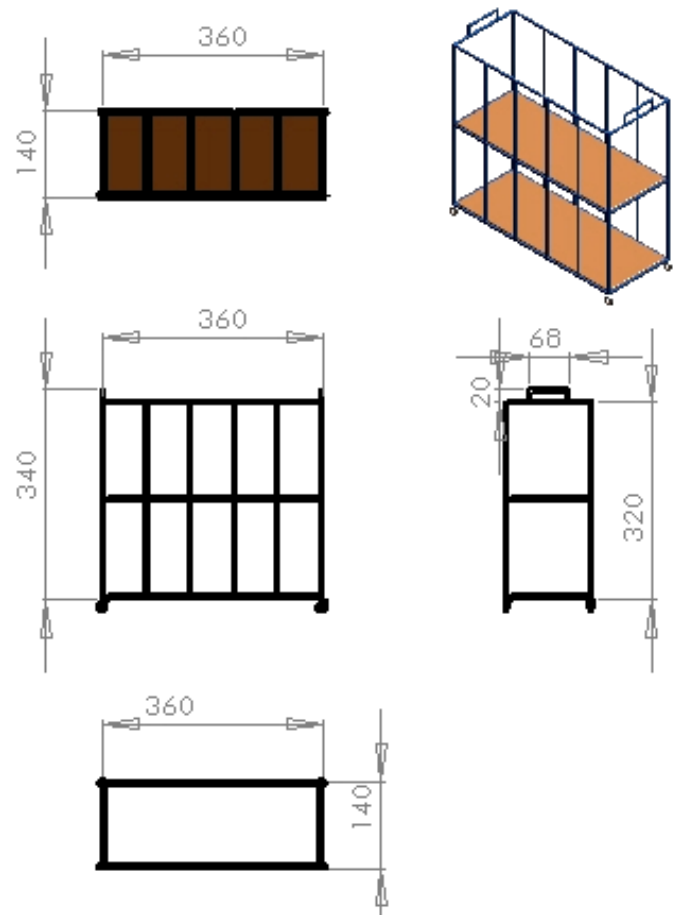

Gambar 5 Dimensi Alat Penyimpanan Kain Usulan

Kelebihan dari alat penyimpanan kain usulan adalah dapat menampung kain secara utuh, dimana dengan menggunakan alat penyimpanan kain saat ini masih terdapat sebagian kain yang keluar dari rak. 


\section{USULAN PERANCANGAN TATA LETAK GUDANG (Johan, dkk.)}

\subsubsection{Perhitungan Kebutuhan Luas Lantai Tata Letak Usulan}

Perhitungan luas lantai menggunakan data persediaan maksimum bulanan gudang dan dimensi rak sebagai alat penyimpanan. Perhitungan luas lantai ditunjukkan pada tabel 4 .

Tabel 4. Perhitungan Luas Lantai Usulan

\begin{tabular}{|c|c|c|c|c|c|c|c|c|c|c|c|c|c|c|c|c|c|}
\hline \multirow[b]{2}{*}{ No. } & \multirow{2}{*}{$\begin{array}{l}\text { Nama } \\
\text { Produk }\end{array}$} & \multirow{2}{*}{$\begin{array}{l}\text { Persediaan } \\
\text { Max/Bulan }\end{array}$} & \multicolumn{3}{|c|}{ Dimensi Kain Datang } & \multirow{2}{*}{$\begin{array}{l}\text { Satuan Bahan } \\
\text { Datang }\end{array}$} & \multicolumn{3}{|c|}{$\begin{array}{c}\text { Keterangan Rak } \\
\text { Dimensi }(\mathrm{cm})\end{array}$} & \multicolumn{3}{|c|}{ Kapasitas Rak } & \multicolumn{2}{|c|}{ Jumlah Rak } & \multirow{2}{*}{$\begin{array}{c}\text { Luas Lantai } \\
\quad\left(\mathrm{cm}^{2}\right)\end{array}$} & \multirow{2}{*}{$\begin{array}{c}\text { Allowance } \\
37 \%\end{array}$} & \multirow{2}{*}{$\begin{array}{l}\text { Total Luas } \\
\text { Lantai }\left(\mathrm{cm}^{2}\right)\end{array}$} \\
\hline & & & Panjang & Lebar & Tinggi / Diameter & & $p$ & $\frac{\mathrm{nsi}(\mathrm{cm}}{\mathrm{l}}$ & $t$ & h & $\mathrm{v}$ & total & Desimal & Round Up & & & \\
\hline 1 & Kain DN & 372 & 180 & 70 & 70 & Gulung & 360 & 140 & 330 & 4 & 4 & 16 & 23,25 & 24 & 1.209 .600 & 449.487 & 1.659 .087 \\
\hline 2 & Kain TN & 579 & 267 & 30 & 30 & Gulung & 360 & 140 & 330 & 4 & 11 & 44 & 13,15909 & 14 & 705.600 & 262.201 & 967.801 \\
\hline 3 & Kain TS & 124 & 270 & 30 & 30 & Gulung & 360 & 140 & 240 & 4 & 8 & 32 & 3,875 & 4 & 201.600 & 74.915 & 276.515 \\
\hline 4 & Kain TV & 381 & 80 & 40 & 30 & Karung & 360 & 140 & 330 & 12 & 8 & 96 & 3,96875 & 4 & 201.600 & 74.915 & 276.515 \\
\hline & & & & & & & & & & & & & & & 2.318 .400 & 861.517 & 3.179.917 \\
\hline
\end{tabular}

Contoh Perhitungan Kain DN:

- Kapasitas rak (h) dihitung dari segi horizontal, yaitu panjang rak dan lebar rak

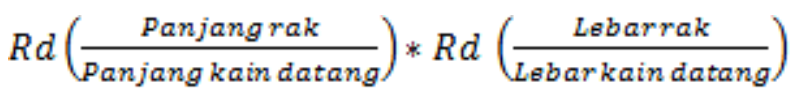


- Penentuan nilai allowance seharusnya berdasarkan dimensi alat material handling serta kemungkinan alat material handling melakukan manuver. Namun karena luas gudang yang ingin dirancang sudah memiliki luas yang tetap, maka penentuan nilai allowance akan disesuaikan dengan luas lantai gudang saat ini. Gambaran dimensi gudang saat ini ditunjukkan dalam gambar 6.

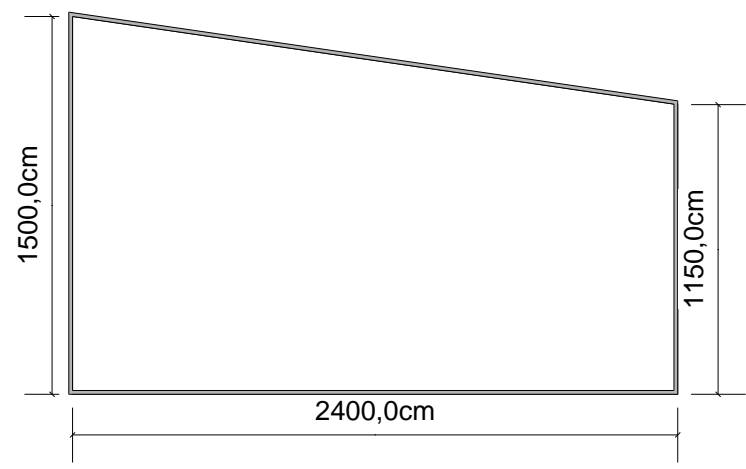

Gambar 6 Gambaran Gudang Saat Ini

Luas gudang saat ini $=$ Luas Persegi + Luas Segitiga

$$
\begin{aligned}
& =(2400 * 1150)+(1 / 2 * 2400 * 350) \\
& =2.760 .000+420.000 \\
& =3.180 .000 \mathrm{~cm}^{2} \approx 318 \mathrm{~m}^{2}
\end{aligned}
$$

Luas lantai total yang dibutuhkan $\quad=2.318 .400 \approx 231,8 \mathrm{~m}^{2}$

$$
\begin{aligned}
\text { Allowance }= & \frac{318 \mathrm{~m}^{2}-231,84 \mathrm{~m}^{2}}{231,84 \mathrm{~m}^{2}} * 100 \%=37,16 \% \\
\text { Allowance } & =\text { Luas lantai } * 37,16 \% \\
& =1.209 .600 * 37,16 \% \\
& =449.487 \mathrm{~cm}^{2}
\end{aligned}
$$

- Total luas lantai yang dibutuhkan untuk menyimpan kain DN $=$ Luas lantai + Allowance $37,16 \%$

$=1.209 .600+449.487=1.659 .087 \mathrm{~cm}^{2}$

\subsubsection{Alat Material Handling Usulan}

Saat ini, perusahaan tidak memiliki alat material handling di dalam gudang. Alat material handling berupa trolley tidak dapat masuk ke dalam gudang, sehingga 2 operator gudang yang melakukan aktivitas material handling (membawa kain). Mereka membawa kain dari pintu luar gudang ke dalam gudang dengan cara kedua ujung kain diangkat di atas bahu. Oleh karena usaha yang dikeluarkan oleh operator sangat besar, disamping membuat storing time maupun handling time lama, maka diusulkan penggunaan trolley kecil sebagai alat material handling usulan seperti yang ditunjukkan pada gambar 7.

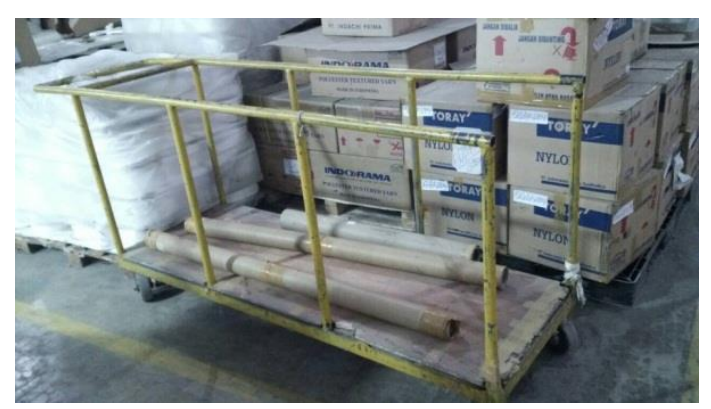

Gambar 7 Trolley Kecil 
Trolley kecil yang berukuran $200 \times 70 \times 100$ dapat masuk ke dalam gudang dengan membawa sejumlah kain tanpa harus membuat operator mengangkut kain satu demi satu yang membutuhkan waktu yang lama. Selain meringankan beban operator, storing time dan handling time juga dapat dikurangi yang akan lebih mempermudah proses penyimpanan dan pengeluaran kain.

\subsubsection{Perhitungan Frekuensi Kain Usulan}

Perhitungan frekuensi dihitung berdasarkan kapasitas alat material handling yang digunakan dan data in dan out per-bulan. Perhitungan frekuensi berfungsi untuk mendapatkan data frekuensi jenis kain atau seberapa sering kain dimasukkan dan dikeluarkan dari gudang yang akan digunakan untuk menghitung skala prioritas kain.

Perhitungan persentase pintu dihitung dari penggunaan 2 pintu sebagai jalur in dan out gudang. Namun pada persentase pintu usulan penggunaan kedua pintu disamaratakan, yaitu 50\%. Dengan demikian, semua jenis kain dapat melewati pintu 1 maupun pintu 2. Perhitungan frekuensi dengan menggunakan trolley kecil sebagai material handling ditunjukkan pada perhitungan dalam tabel 5.

Tabel 5 Perhitungan Frekuensi Kain Usulan

\begin{tabular}{|c|c|c|c|c|c|c|c|c|c|c|c|c|c|c|}
\hline \multirow{2}{*}{ No. } & \multirow{2}{*}{ Jenis Corak } & \multirow{2}{*}{$\begin{array}{c}\text { Satuan bahan } \\
\text { datang }\end{array}$} & \multirow{2}{*}{$\begin{array}{c}\text { Frekuensi Jumlah } \\
\text { Kain/bulan }\end{array}$} & \multicolumn{3}{|c|}{ Dimensi bahan datang ( $\mathrm{cm}$ ) } & \multirow{2}{*}{$\begin{array}{l}\text { Material } \\
\text { Handling }\end{array}$} & \multicolumn{3}{|c|}{ Dimensi Trolley } & \multicolumn{2}{|c|}{ Kapasitas Trolley } & \multirow{2}{*}{$\begin{array}{c}\text { Kapasitas } \\
\text { Angkut }\end{array}$} & \multirow{2}{*}{$\begin{array}{c}\text { Frekuensil } \\
\text { Bulan }\end{array}$} \\
\hline & & & & $p$ & l & $t$ & & Panjang & Lebar & Tinggi & $\mathrm{h}$ & $\mathrm{v}$ & & \\
\hline 1 & Kain DN & Gulung & \begin{tabular}{|l|}
823 \\
\end{tabular} & 180 & 70 & 70 & Trolley kecil & 200 & 70 & 100 & 1 & 2 & 2 & 412 \\
\hline 2 & Kain TN & Gulung & 1145 & 267 & 30 & 30 & Trolley kecil & 200 & 70 & 100 & 1 & 3 & 3 & 382 \\
\hline 3 & Kain TS & Gulung & 183 & 270 & 30 & 30 & Trolley kecil & 200 & 70 & 100 & 1 & 3 & 3 & 61 \\
\hline 4 & Kain TV & Karung & 611 & 80 & 40 & 30 & Trolley kecil & 200 & 70 & 100 & 2 & 3 & 6 & 102 \\
\hline
\end{tabular}

Keterangan dan contoh perhitungan kain DN:

- Frekuensi jumlah kain/bulan didapatkan dari data persediaan maksimum bulanan gudang pada tabel 5.

- Material handling yang digunakan adalah trolley kecil karena trolley besar hanya berfungsi untuk membawa kain dari lantai produksi ke depan gudang, sedangkan yang mengangkut gulungan kain dari luar gudang ke dalam gudang adalah operator gudang dengan menggunakan trolley kecil.

- Kapasitas angkut adalah jumlah gulungan kain DN yang dapat dibawa oleh trolley kecil dalam sekali angkut adalah 2 gulungan kain.

- Frekuensi/Bulan = Data maksimum gudang/Kapasitas angkut $=823 / 2=412 \mathrm{kali}$

\subsubsection{Penentuan Skala Prioritas Usulan}

Penentuan skala prioritas (rank) berdasarkan luas lantai, dimensi alat penyimpanan, dan frekuensi kain datang. Penentuan rank skala prioritas ditunjukkan pada tabel 6.

Tabel 6 Skala Prioritas Usulan

\begin{tabular}{|c|c|r|r|r|c|c|c|c|}
\hline No. & Jenis Corak & Luas Total Lantai & Luas Pallet & S & T & T/S & Rank & Warna \\
\hline 1 & Kain DN & 1.209 .600 & 50.400 & 24 & 412 & 17,167 & 4 & \\
\hline 2 & Kain TN & 705.600 & 50.400 & 14 & 382 & 27,286 & 2 & \\
\hline 3 & Kain TS & 201.600 & 50.400 & 4 & 61 & 15,250 & 1 & \\
\hline 4 & Kain TV & 201.600 & 50.400 & 4 & 102 & 25,500 & 3 & \\
\hline
\end{tabular}

Dari tabel 6 terlihat bahwa kain TS diberikan rank 1, karena kain TS adalah kain spandek yang berat dan memerlukan banyak perlakuan khusus, sehingga harus diberikan rank 1, yang berarti disimpan di lokasi yang merupakan lokasi fast moving product 
Contoh Perhitungan Kain DN :

- S (Storage Bays) adalah jumlah slot lokasi yang diperlukan untuk menyimpan kain DN $\mathrm{S}=\frac{\text { Total Luas Lantai }}{\text { Luas Rak }}=\frac{1.209 .600}{50.400}=24$ slot

- Nilai T (Throughput) diambil dari tabel frekuensi kain yaitu frekuensi/bulan

- T/S adalah perbandingan antara frekuensi dan jumlah slot. Nilai T/S berfungsi sebagai penentu apakah produk tersebut merupakan fast moving product atau slow moving product.

$\mathrm{T} / \mathrm{S}=\frac{\text { Throughput }}{\text { Slot }}=\frac{412}{24}=17,167$ throughput/slot

- Penentuan rank berdasarkan nilai T/S paling besar. Rank pertama diberikan untuk produk yang akan disimpan di lokasi yang merupakan lokasi fast moving product dan seterusnya hingga rank terakhir yang disimpan di lokasi yang merupakan lokasi slow moving product.

\subsubsection{Perhitungan Nilai Lokasi Tata Letak Usulan dengan Metode Perhitungan Jarak Rectilinear}

Perhitungan nilai lokasi menggunakan metode perhitungan jarak rectilinear, yaitu perkalian antara jarak dari pintu ke lokasi dengan persentase pintu. Perhitungan nilai lokasi diperlukan untuk dapat menentukan letak produk yang merupakan fast moving product dan slow moving product. Semakin rendah skor lokasi, maka semakin dekat jarak lokasi tersebut dengan pintu keluar masuk gudang.

Perhitungan nilai lokasi menggunakan 2 pintu dalam proses pengeluaran dan pemasukan barang dan perhitungan nilai lokasi dengan menggunakan kotak 360x140 ditunjukkan pada gambar 8 dan gambar 9.

\begin{tabular}{|l|c|c|c|c|c|c|c|c|c|c|c|c|c|c|c|}
\hline 33 & 34 & 35 & 36 & 37 & 38 & 39 & 40 & 41 & 42 & 43 & 44 & 45 & 46 & 47 & 48 \\
\hline 17 & 18 & 19 & 20 & 21 & 22 & 23 & 24 & 25 & 26 & 27 & 28 & 29 & 30 & 31 & 32 \\
\hline 1 & 2 & 3 & 4 & 5 & 6 & 7 & 8 & 9 & 10 & 11 & 12 & 13 & 14 & 15 & 16 \\
\hline
\end{tabular}

Gambar 8 Penomoran Lokasi Perhitungan Jarak Rectilinear

Contoh perhitungan :

$\mathrm{S}_{1}=$ Jarak ke titik tengah lokasi dari $\mathrm{P}_{1}$

$\mathrm{S}_{2}=$ Jarak ke titik tengah lokasi dari $\mathrm{P}_{2}$

- Lokasi $1=\left(\right.$ Jarak ke titik tengah lokasi 1 dari $\mathrm{P}_{1} *$ Persentase $\left.\mathrm{P}_{1}\right)+$

(Jarak ke titik tengah lokasi 1 dari $\mathrm{P}_{2} *$ Persentase $\mathrm{P}_{2}$ )

$=((0,7+1,8) * 50 \%)+(18,9+1,8) * 50 \%)=11,60$

- Lokasi $17=\left(\right.$ Jarak ke titik tengah lokasi 17 dari $\mathrm{P}_{1} *$ Persentase $\left.\mathrm{P}_{1}\right)+$

(Jarak ke titik tengah lokasi 17 dari $\mathrm{P}_{2} *$ Persentase $\mathrm{P}_{2}$ )

$=((0,7+5,4) * 50 \%)+(18,9+1,8) * 50 \%)=15,20$

Setelah dilakukan perhitungan nilai lokasi secara rectilinear dengan ukuran kotak 360 x 140, diperoleh hasil nilai lokasi ditunjukkan pada gambar 9. 
USULAN PERANCANGAN TATA LETAK GUDANG (Johan, dkk.)

\begin{tabular}{|c|c|c|c|c|c|c|c|c|c|c|c|c|c|c|c|}
\hline 18,80 & 18,10 & 18,10 & 18,10 & 18,10 & 18,10 & 18,10 & 18,10 & 18,10 & 18,10 & 18,10 & 18,10 & 18,10 & 18,10 & 18,80 & 20,20 \\
\hline 15,20 & 14,50 & 14,50 & 14,50 & 14,50 & 14,50 & 14,50 & 14,50 & 14,50 & 14,50 & 14,50 & 14,50 & 14,50 & 14,50 & 15,20 & 16,60 \\
\hline 11,60 & 10,90 & 10,90 & 10,90 & 10,90 & 10,90 & 10,90 & 10,90 & 10,90 & 10,90 & 10,90 & 10,90 & 10,90 & 10,90 & 11,60 & 13,00 \\
\hline
\end{tabular}

Gambar 9 Hasil Perhitungan Nilai Lokasi

Penentuan lokasi corak kain ditentukan berdasarkan lokasi dengan nilai terendah, yang berarti lokasi tersebut merupakan lokasi untuk fast moving product, seperti ditunjukkan pada gambar 10 , sedangkan untuk penentuan fast moving product maupun slow moving product dapat dilihat berdasarkan hasil perhitungan skala prioritas pada tabel 6 .

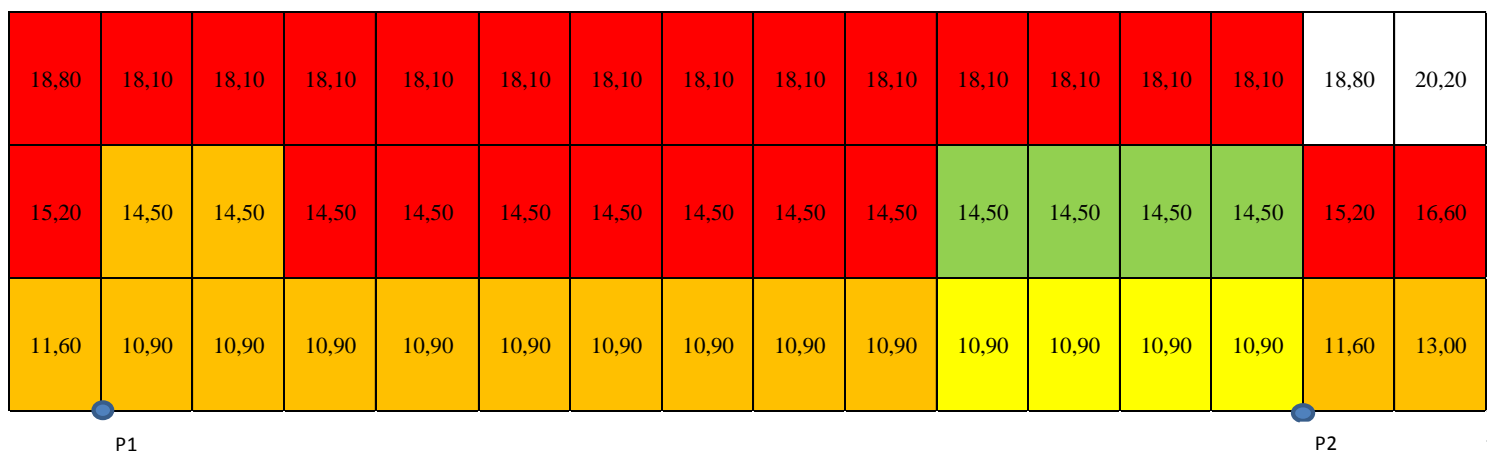

Gambar 10 Tata Letak Optimum

Keterangan warna :

\begin{tabular}{|l|c|}
\hline & Kain DN \\
\hline & Kain TN \\
\hline & Kain TS \\
\hline & Kain TV \\
\hline
\end{tabular}

Perhitungan jarak rata-rata dari lokasi ke pintu gudang dihitung berdasarkan nilai lokasi setiap corak kain dan dibagi dengan jumlah lokasi corak tersebut seperti ditunjukkan pada tabel 7.

Tabel 7 Perhitungan Jarak Rata-rata (Sebelum Penyesuaian)

\begin{tabular}{|c|c|c|c|c|}
\hline Jenis Corak & S & Total Jarak & Jarak Rata-rata & Rank \\
\hline Kain DN & 24 & 417,1 & 17,4 & 4 \\
\hline Kain TN & 14 & 163,3 & 11,7 & 2 \\
\hline Kain TS & 4 & 43,6 & 10,9 & 1 \\
\hline Kain TV & 4 & 58,0 & 14,5 & 3 \\
\hline
\end{tabular}

Contoh perhitungan kain DN:

- $\mathrm{S}=$ Jumlah rak/pallet alat penyimpanan

- Total jarak = Penjumlahan dari skor jarak untuk setiap lokasi kain DN

- Jarak rata-rata $=\frac{\text { Total jarak }}{S}=\frac{417,1}{24}$

$$
=17,4 \mathrm{~m}
$$

- Rank ditentukan dari jarak rata-rata terkecil hingga terbesar. Penentuan rank diperlukan untuk menyesuaikan penentuan lokasi yaitu pada saat penyesuaian lokasi sehingga setelah dilakukan 
penyesuaian, lokasi yang baru tersebut tidak boleh menyalahi aturan rank pada perhitungan jarak rata-rata tabel 7.

- Pada perhitungan jarak rata-rata kain DN memiliki jarak rata-rata terbesar sehingga diberikan rank 4.

\subsubsection{Tata Letak Setelah Penyesuaian}

Tata letak setelah penyesuaian didapatkan setelah melakukan alokasi penentuan letak produk di lokasi fast moving product dan lokasi slow moving product. Namun, pada tata letak optimum masih terdapat banyak kekurangan, seperti yang ditunjukkan pada gambar 10, yaitu letak produk yang sejenis saling terpisah. Oleh karena itu dilakukanlah penyesuaian, yaitu melakukan perpindahan lokasi produk supaya produk yang sejenis tidak saling berjauhan, seperti ditunjukkan pada gambar 11. Penentuan tata letak usulan setelah penyesuaian berdasarkan tata letak yang sudah dilakukan penyesuaian, yaitu menyesuaikan letak-letak lokasi supaya berdekatan, namun tidak menyalahi aturan rank skala prioritas.

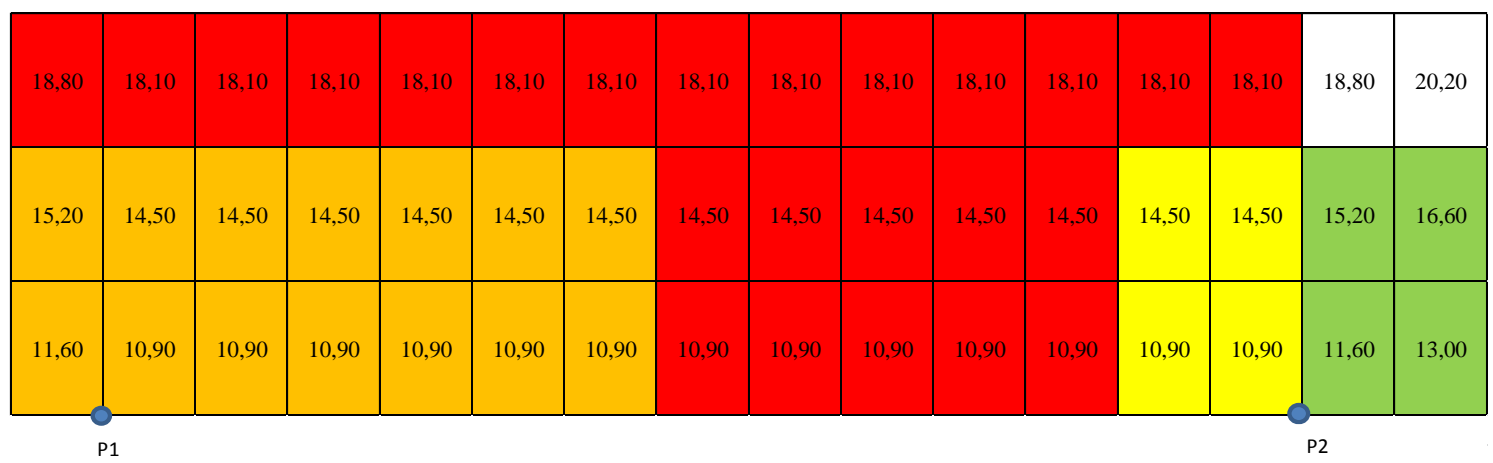

Gambar 11 Tata Letak Setelah Penyesuaian

Keterangan warna :

\begin{tabular}{|l|c|}
\hline & Kain DN \\
\hline & Kain TN \\
\hline & Kain TS \\
\hline & Kain TV \\
\hline
\end{tabular}

Perhitungan jarak rata-rata setelah dilakukan penyesuaian ditunjukkan dalam tabel 8 .

Tabel 8 Perhitungan Jarak Rata-rata (Setelah Penyesuaian)

\begin{tabular}{|c|c|c|c|c|}
\hline Jenis Corak & S & Total Jarak & Jarak Rata-rata & Rank \\
\hline Kain DN & 24 & 381,1 & 15,9 & 4 \\
\hline Kain TN & 14 & 179,2 & 12,8 & 2 \\
\hline Kain TS & 4 & 50,8 & 12,7 & 1 \\
\hline Kain TV & 4 & 56,4 & 14,1 & 3 \\
\hline
\end{tabular}

Dari tabel 8 terlihat tidak terdapatnya perubahan rank pada setiap kain corak. Hal ini menunjukkan bahwa penyesuaian yang dilakukan tidak menyalahi aturan skala prioritas.

\subsubsection{Tata Letak Usulan Akhir}

Memproyeksikan hasil penyusunan tata letak usulan yang telah disesuaikan (Gambar 11) ke tata letak sebenarnya dalam bentuk 20x20 seperti ditunjukkan pada gambar 12 bertujuan untuk mendapatkan jarak rata-rata sebenarnya. 
USULAN PERANCANGAN TATA LETAK GUDANG (Johan, dkk.)

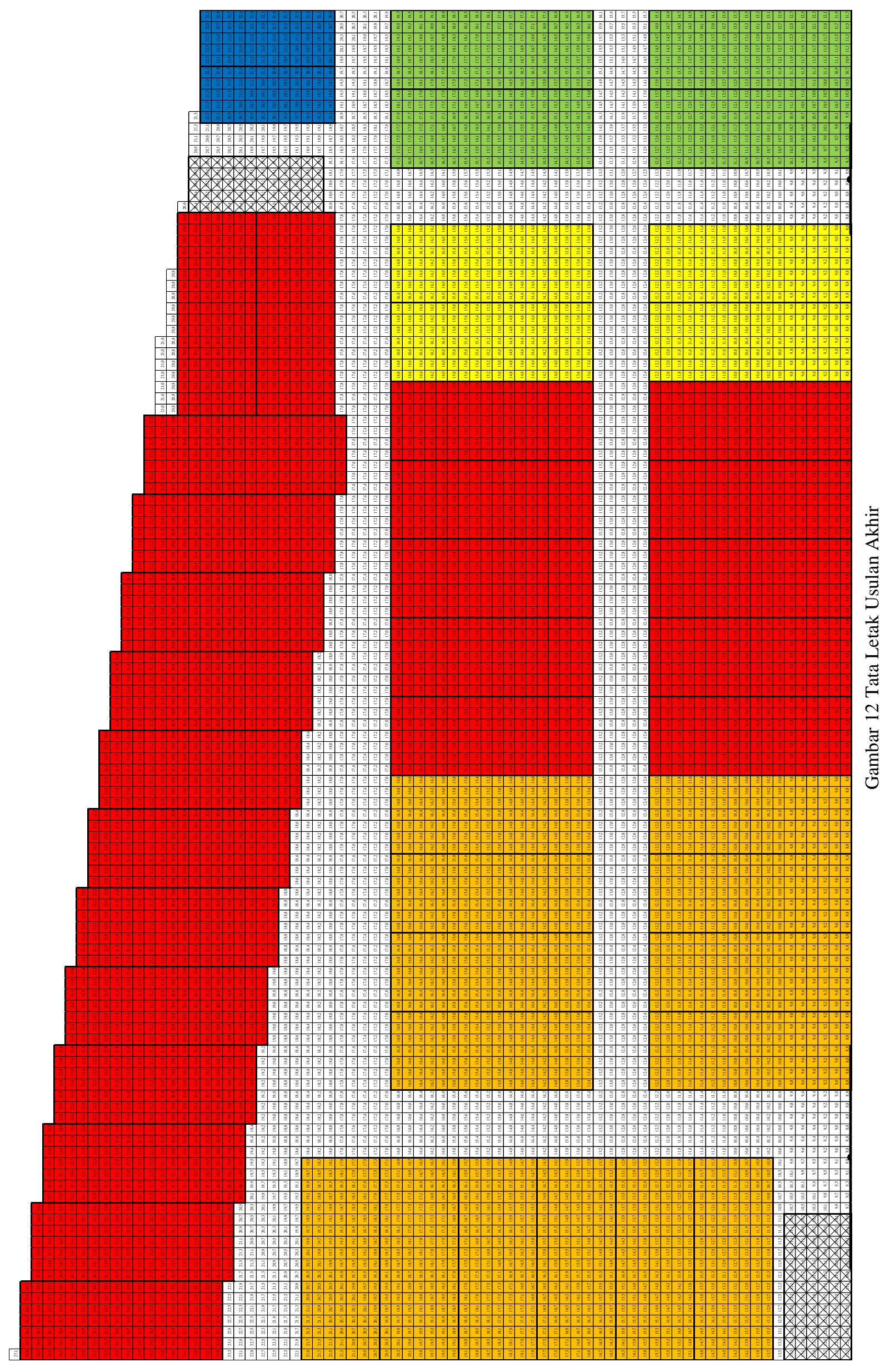

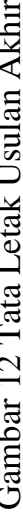


Perhitungan jarak rata-rata aktual tata letak usulan dengan menggunakan tata letak gudang sesungguhnya $(20 \times 20 \mathrm{~cm})$ ditunjukkan pada tabel 9.

Tabel 9 Perhitungan Jarak Rata-rata Tata Letak Usulan Akhir

\begin{tabular}{|c|c|c|c|c|c|}
\hline Jenis Corak & Jumlah Pallet /Rak & S & Total Jarak & Jarak Rata-rata & Rank \\
\hline Kain DN & 24 & 3024 & 52722,00 & 17,435 & 4 \\
\hline Kain TN & 14 & 1764 & 25074,00 & 14,214 & 2 \\
\hline Kain TS & 4 & 504 & 6400,80 & 12,700 & 1 \\
\hline Kain TV & 4 & 504 & 7257,60 & 14,400 & 3 \\
\hline
\end{tabular}

\subsection{Analisis}

\subsubsection{Analisis Tata Letak Kain Usulan}

Tata letak kain usulan menggunakan metode class-based storage, dimana metode tersebut cocok diterapkan di gudang kain grey PT Heksatex Indah. Dengan metode ini kain ditempatkan berdasarkan jenis kain, yaitu: kain DN, kain TN, kain TS, dan kain TV, sehingga waktu pencarian kain dapat dipersingkat karena kain disimpan berdasarkan jenis kain.

Pada tata letak kain usulan penggunaan pintu disamakan menjadi 50\% untuk masing-masing pintu, karena pada tata letak kain usulan gang tidak digunakan untuk menyimpan barang, sehingga jalur operator ke area pintu 1 ataupun 2 tidak terhalang oleh kain. Dengan demikian kedua pintu dapat digunakan untuk jalur keluar-masuk kain.

Tata letak usulan juga menggunakan alat material handling baru yaitu trolley kecil seperti yang ditunjukkan pada gambar 7 yang akan meringankan beban kerja operator sehingga operator tidak perlu membawa kain satu per satu dari pintu gudang menuju lokasi penyimpanan.

\subsubsection{Analisis Kelebihan Tata Letak Kain Usulan}

Tata letak kain usulan dibandingkan dengan tata letak kain saat ini memiliki keunggulankeunggulan secara kualitatif seperti yang diperlihatkan dalam tabel 10.

Tabel 10 Perbandingan Metode Saat Ini dan Usulan

\begin{tabular}{|c|c|}
\hline Layout Saat Ini & Layout Usulan \\
\hline $\begin{array}{c}\text { Metode tata letak gudang menggunakan metode random } \\
\text { storage }\end{array}$ & $\begin{array}{c}\text { Metode tata letak gudang menggunakan metode class- } \\
\text { based storage }\end{array}$ \\
\hline Tata letak gudang saat ini yang kurang teratur & Tata letak gudang yang lebih teratur \\
\hline Tidak terdapat alat material handling & $\begin{array}{c}\text { Terdapat alat material handling yang mempermudah } \\
\text { pekerjaan operator gudang }\end{array}$ \\
\hline Terdapat produk kain atau barang di area gang & Tidak terdapat produk kain atau barang di area gang \\
\hline $\begin{array}{c}\text { Sulit dalam pencarian kain karena letak kain yang masih } \\
\text { random }\end{array}$ & $\begin{array}{c}\text { Lebih mudah dalam pencarian kain karena disimpan per } \\
\text { kelas }\end{array}$ \\
\hline $\begin{array}{c}\text { Alat penyimpanan yang kurang memadai (Ukuran kain } \\
\text { lebih panjang dari alat penyimpanan) }\end{array}$ & $\begin{array}{c}\text { Modifikasi alat penyimpanan yang baru sehingga dapat } \\
\text { memuat semua jenis kain }\end{array}$ \\
\hline
\end{tabular}

Perhitungan jarak saat ini menggunakan metode random storage, sehingga ketika kain dimasukkan ke dalam gudang, kain disimpan di lokasi yang available saat itu. Dengan demikian perhitungan jarak dilakukan dari pintu ke blok, karena kain disimpan secara acak, sehingga susah untuk memastikan lokasi jenis kain dengan pasti. Sedangkan tata letak kain usulan dirancang menggunakan metode class-based storage, dimana lokasi gudang dibagi menjadi 4 lokasi, yaitu 
lokasi kain DN, kain TN, kain TS, dan kain TV. Perhitungan jarak dihitung dari pintu ke setiap lokasi. Perbandingan kedua tata letak ditunjukkan pada tabel 11

Tabel 11 Perbandingan Jarak Rata-rata Saat Ini dan Usulan

\begin{tabular}{|c|c|c|c|c|c|c|c|c|c|c|}
\hline \multicolumn{6}{|c|}{ Saat Ini (Random Storage ) } & \multicolumn{5}{|c|}{ Usulan (Class Based Storage ) } \\
\hline \multirow{2}{*}{ Jenis Kain } & \multirow{2}{*}{ Area } & \multirow{2}{*}{ Total Jarak (m) } & \multirow{2}{*}{ S (Lokasi 20 x 20) } & \multicolumn{2}{|c|}{ Jarak Rata-rata (m) } & \multirow{2}{*}{ Jenis Kain } & \multirow{2}{*}{ Total Jarak (m) } & \multirow{2}{*}{$\mathrm{S}($ Lokasi 20 x 20) } & \multicolumn{2}{|c|}{ Jarak Rata-rata (m) } \\
\hline & & & & Per Area & Total & & & & Per Area & Total \\
\hline \multirow{8}{*}{$\begin{array}{c}\text { Semua Jenis } \\
\text { Kain }\end{array}$} & Blok A & 15797,65 & 819 & 19,29 & \multirow{8}{*}{123,28} & \multirow{2}{*}{ Kain DN } & \multirow{2}{*}{52722,00} & \multirow{2}{*}{3024} & \multirow{2}{*}{17,43} & \multirow{8}{*}{58,75} \\
\hline & Blok B & 9782,45 & 567 & 17,25 & & & & & & \\
\hline & Blok C & 8761,85 & 567 & 15,45 & & \multirow{2}{*}{ Kain TN } & \multirow{2}{*}{25074,00} & \multirow{2}{*}{1764} & \multirow{2}{*}{14,21} & \\
\hline & Blok D & 6947,45 & 567 & 12,25 & & & & & & \\
\hline & $\mathrm{B} \log \mathrm{E}$ & 2108,83 & 180 & 11,72 & & \multirow{2}{*}{ Kain TS } & \multirow{2}{*}{6400,80} & \multirow{2}{*}{504} & \multirow{2}{*}{12,7} & \\
\hline & $\mathrm{B} \log \mathrm{F}$ & 19516,35 & 810 & 24,09 & & & & & & \\
\hline & $\mathrm{B} \log \mathrm{G}$ & 6438,71 & 693 & 9,29 & & \multirow{2}{*}{ Kain TV } & \multirow{2}{*}{7257,60} & \multirow{2}{*}{504} & \multirow{2}{*}{14,4} & \\
\hline & Kain di Gang & 22110,79 & 1587 & 13,93 & & & & & & \\
\hline
\end{tabular}

\subsubsection{Analisis Kelebihan Alat Material Handling Usulan}

Saat ini pemindahan kain dari pintu gudang ke lokasi penyimpanan tidak menggunakan alat material handling, pemindahan dilakukan dengan cara diletakkan di atas bahu 2 operator yang membawanya. Hal ini membuat usaha yang dikeluarkan untuk memindahkan kain cukup besar dan lama kelamaan dapat menyebabkan nyeri bahu. Oleh karena itu diusulkan adanya alat material handling. Alat material handling usulan memiliki ukuran $140 \times 70 \times 90 \mathrm{~cm}$ sehingga trolley kecil ini dapat melewati gang yang berukuran $100 \mathrm{~cm}$. Trolley kecil memiliki kapasitas penyimpanan 2 untuk kain DN, 3 untuk kain TN dan TS, dan 6 kain TV. Alasan pemilihan trolley kecil sebagai alat material handling dikarenakan kapasitas produksi untuk setiap jenis corak maksimal hanya 2 gulung kain untuk corak kain DN dan 3 gulung kain untuk jenis corak kain lainnya, sehingga berdasarkan kapasitas produksi dan ukuran trolley yang dapat masuk ke area gang yang kecil tersebut diusulkan penggunaan alat material handling trolley kecil.

\subsubsection{Analisis Kelebihan Alat Penyimpanan Usulan}

Kain yang disimpan di gudang memiliki ukuran panjang maksimum $270 \mathrm{~cm}$ yaitu kain TS, sehingga ketika kain disimpan di rak dan pallet saat ini yang memiliki ukuran 180 × 140 × 320, sebagian kain masuk ke area gang yang membuat area gang semakin kecil. Oleh karena itu, dilakukan modifikasi alat penyimpanan saat ini dengan menggabungkan 2 rak tingkat 2 berukuran 180 × 140 × 320 ke arah panjang menjadi 1 rak berukuran 360 × 140 × 320. Dengan demikian, seluruh bagian kain dapat tersangga rak dan kain tidak menutupi area gang. Perbandingan dari alat penyimpanan saat ini dan usulan ditunjukkan pada tabel 12 .

Tabel 12 Perbandingan Alat penyimpanan Saat Ini dan Usulan

\begin{tabular}{|l|l|}
\hline \multicolumn{1}{|c|}{ Alat Penyimpanan Kain Saat Ini } & \multicolumn{1}{c|}{ Alat Penyimpanan Kain Usulan } \\
\hline $\begin{array}{l}\text { Menggunakan Pallet, Rak tingkat 2, Rak tingkat 3, dan } \\
\text { Kain disusun panjang dan saling menumpuk }\end{array}$ & $\begin{array}{l}\text { Menggunakan Pallet, Rak usulan, dan Rak tingkat 3 (Kain } \\
\text { random) }\end{array}$ \\
\hline $\begin{array}{l}\text { Rak tidak dapat menyimpan semua jenis kain sehingga } \\
\text { terdapat sebagian kain masuk ke area gang }\end{array}$ & Rak usulan dapat menyimpan semua jenis kain \\
\hline Kain spandek tidak memiliki alat penyimpanan & Kain spandek dapat disimpan di rak usulan \\
\hline $\begin{array}{l}\text { Kain spandek membutuhkan tempat yang luas karena } \\
\text { tidak dapat ditumpuk lebih dari 4 tumpukan }\end{array}$ & $\begin{array}{l}\text { Kain spandek dapat ditumpuk 8 pada tingkat pertama dan } \\
\text { tingkat kedua rak usulan }\end{array}$ \\
\hline
\end{tabular}




\section{Kesimpulan dan Saran}

\subsection{Kesimpulan}

Dari penelitian yang dilakukan, penulis dapat menarik kesimpulan sebagai berikut:

1. Tata letak kain usulan mengikuti metode class-based storage, dimana kain dikelompokkan berdasarkan jenis kain dengan kode DN, TN, TS, dan TV.

2. Tata letak kain usulan memiliki kelebihan, sebagai berikut:

a. Letak kain lebih rapi dan teratur, sehingga memudahkan operator dalam mencari kain yang diinginkan.

b. Gang tidak digunakan untuk menyimpan kain, sehingga operator mudah melakukan aktivitas pemasukan dan pengeluaran kain. Selain itu, jenis kain yang sama berada di satu lokasi yang membuat operator tidak susah mencari kain.

c. Jarak tempuh rata-rata dari pintu gudang ke lokasi penyimpanan yang lebih pendek dengan besar pengurangan jarak sejauh $64.53 \mathrm{~m}$.

3. Alat material handling trolley kecil berukuran 140 x 70 x 90 cocok dengan tata letak kain usulan karena dapat masuk ke dalam gang/aisle dan memiliki kapasitas angkut yang sesuai dengan kapasitas produksi per corak.

4. Alat penyimpanan kain yang sebaiknya digunakan perusahaan adalah memodifikasi alat penyimpanan kain saat ini dengan cara menggabungkan 2 buah rak tingkat 2 yang masingmasing berukuran $180 \times 140 \times 320$ menjadi 1 buah rak tingkat 2 yang lebih panjang dengan ukuran 360 x $140 \times 320$.

\subsection{Saran}

\subsubsection{Saran untuk Perusahaan}

Saran yang diberikan untuk perusahaan adalah tiap jenis kain memiliki corak yang berbedabeda.Oleh karena itu, sebaiknya perusahaan melakukan pengelompokkan kain berdasarkan coraknya untuk masing-masing jenis kain.

\subsubsection{Saran untuk Penelitian Lanjutan}

Saran untuk penelitian lanjutan, sebaiknya tata letak usulan memperhitungkan pula faktor biaya, yaitu OMH (Ongkos Material Handling).

\section{Daftar Pustaka}

Francis, Richard. L, et al., (1992), Facility Layout and Location: An Analytical Approach, Prentice Hall.

Sofyan, Diana Khairani, (2013), Perencanaan \& Pengendalian Produksi, Graha Ilmu, Yogyakarta, 2013.

Tompkins, et al., (2003), Facilities Planning, John Wiley \& Sons, Inc, United States of America.

Warman, John, (1995), Manajemen Pergudangan, Pustaka Sinar Harapan, Jakarta.

Wignjosoebroto, Sritomo, (2003), Tata Letak Pabrik dan Pemindahan Bahan, Guna Widya, Surabaya.

Yamit, Zulian, (1999), Manajemen Persediaan, EKONISIA Fakultas Ekonomi UII, Yogyakarta. 